\title{
Defatted corn-germ flour as an ingredient in swine feed and a source of endogenous antioxidants in pork ${ }^{1}$
}

\section{Farelo de gérmen de milho desengordurado como ingrediente na dieta de suínos e fonte de antioxidante endógeno na carne}

\author{
Mara Regina Ribeiro da Costa²; Caio Abércio da Silva ${ }^{3}$; Ana Maria Bridi ${ }^{3 *}$; \\ Mauro Sérgio Ywazaki ${ }^{4}$; Piero da Silva Agostini ${ }^{4}$; \\ Danyel Bueno Dalto²; Roberta Abrami Monteiro da Silva²
}

\begin{abstract}
The effects of including defatted corn-germ flour (DCGF), a source of phytic acid, as an ingredient in pig feed for different periods in the growing-finishing phase were evaluated with respect to feed performance, carcass characteristics and meat quality. The test group consisted of 24 male pigs from the same genetic background, with an average initial weight of $75.41 \pm 4.41 \mathrm{~kg}$ and an average age of 123 days. The treatments consisted of adding 50\% DCGF to the feed at 0, 7, 14 and 21 days before slaughter. The zootechnical performance, carcass characteristics, meat quality and antioxidant effects of phytic acid were evaluated through the analysis of lipid oxidation in the meat of the slaughtered animals. There were no effects $(\mathrm{P}>0.05)$ for any period of DCGF feed supplementation on the zootechnical performance or carcass characteristics. Refrigerated meat showed less oxidation as the length of the DCGF-inclusion period in the diet was increased.
\end{abstract}

Key words: Alternative feed, lipid oxidation, phytate, phytate acid

\section{Resumo}

O experimento avaliou os efeitos de diferentes períodos de inclusão do farelo de gérmen de milho desengordurado (FGMD), como ingrediente e fonte de ácido fítico em rações de suínos em fase de terminação, sobre o desempenho, características de carcaça e qualidade da carne. Foram utilizados 24 suínos machos de mesma genética comercial com peso médio inicial de 75,41 $\pm 4,41 \mathrm{~kg}$ e idade média de 123 dias. Os tratamentos corresponderam a inclusão de 50\% de FGMD na ração nos períodos de 0, 7, 14 e 21 dias antes ao abate. Foram avaliados o desempenho zootécnico, as características de carcaça e de qualidade da carne e o efeito antioxidante do ácido fítico, através da análise de oxidação lipídica na carne. O delineamento experimental utilizado foi em blocos (peso inicial dos animais) ao acaso, com 4 tratamentos e 6 repetições por tratamento. Não houve efeito $(P>0,05)$ do tempo de inclusão do FGMD na dieta no desempenho zootécnico e nas características de carcaça. Na qualidade de carne houve efeito linear decrescente $(\mathrm{P} \leq 0.05)$ na oxidação lipídica da carne mantida em refrigeração durante 7 dias. A carne refrigerada apresentou menor oxidação com o aumentou do período de inclusão de FGMD nas rações.

Palavras-chave: Ácido fítico, alimento alternativo, fitase, oxidação lipídica

\footnotetext{
1 Parte da Tese Doutorado do primeiro autor em Ciência Animal, Universidade Estadual de Londrina, UEL, Londrina, PR.

2 Discente(s) de Doutorado do Programa de Pós-Graduação em Ciência Animal, Universidade Estadual de Londrina, UEL, Londrina, PR. E-mail: dada_costa@hotmail.com; danyeldb@hotmail.com; ro_abrami@hotmail.com

3 Profs. Drs. do Dept ${ }^{\circ}$ de Zootecnia, UEL, Londrina, PR. E-mail: casilva@uel.br; ambridi@uel.br

4 Discente(s) de Mestrado do Programa de Pós-Graduação em Ciência Animal, UEL, Londrina, PR. E-mail: mauro_ywazaki@ hotmail.com; pieroagostini@hotmail.com

* Author for correspondence
} 


\section{Introduction}

Lipids are responsible for sensory characteristics in foods such as meats, e.g., flavor, color, aroma and juiciness. In pigs, the lipid composition of the meat and its antioxidant profile can be accomplished through changes in the diet.

Lipid oxidation results from a series of reactions that occur mainly in polyunsaturated fatty acids (DUTHIE, 1993) through the action of factors such as oxygen, light and temperature and is catalyzed by the presence of transition metals such as iron and zinc (MORRISSEY et al., 1998; FERRARI, 1999). The consequential effects of these reactions involve a reduction of food quality, a loss of nutritional value, and changes in sensory characteristics, in addition to the generation of toxic products, which can pose risks to consumer health (GHIRETTI et al., 1997; LEE; HENDRICKS, 1995; DUTHIE, 1993). According to Morrissey et al. (1998), damage due to lipid oxidation in vivo is minimized by protective substances such as endogenous antioxidants and metal-scavenging proteins. However, when an animal is slaughtered, events linked to the sacrifice and the transformation of muscle into meat lead to the loss of the action of these protective agents and the acceleration of lipid oxidation (MORRISSEY et al., 1998; FERRARI, 1999).

An effective way to prevent or minimize damage from lipid oxidation in meat is by the use of supplemental antioxidants. Among the various products available, naturally occurring antioxidants administered in animal diets have been the subject of recent research as a result of the major consumer concern for healthy foods.

Phytic acid (inositol hexaphosphate), a complex structure commonly present in cereals, has demonstrated an important antioxidant action in meat, in contrast to the antinutritional effect it imparts to monogastric animals by sequestering phosphorus and by chelating minerals and amino acids in the diet (FIREMAN; FIREMAN; 1998;
SEYNAEVE et al., 2000; SELLE et al., 2000). Although the concept of an association between phytic acid and nutritional deficiency prevails, Seynaeve et al. (2000) indicated that animals can make some use of this complex, suggesting that the inositol hexaphosphate found in many bodily tissues originates in the diet (GRASES; SIMONET; PRIETO, 2001). Muscle tissue represents, in this respect, a major phytic acid storage site (SAKAMOTO; VUCENIK ; SHAMSUDDIN, 1993).

Other studies have indicated the beneficial effects of phytic acid in the prevention of diseases related to oxidation (GRAF; EATON, 1990; ZHOU; ERDMAN JUNIOR, 1995), in the reduction of kidney stones (GRAF; EATON, 1990), and in the decrease of cholesterol and triglyceride levels in the plasma (JARIWALLA et al., 1990). As an antioxidant, the effect of phytic acid is related to its chelation of iron, a potent oxidation catalyst (EMPSON; LABUZA; GRAF 1991; GRAF; EATON, 1990) normally present in high levels in pork.

Given the presence of phytic acid in grains and their by-products, defatted corn-germ flour (DCGF), an ingredient derived from the extraction of corn oil that has a high concentration of inositol hexaphosphate compared to corn, has been used as feed for pigs, poultry and pets. In pig diets, DCGF can be added to the feed for the growing-finishing stage at rates up to $40 \%$ without compromising performance and carcass characteristics (SOARES et al., 2004), with proven antioxidant effects on the meat (HARBACH et al., 2007).

The objective of this study was to evaluate the effects of DCGF inclusions for different periods during the growing-finishing feeding of pigs to minimize the risks of a possible nutritional impairment on feed performance, carcass characteristics, meat quality and the shelf life of the meat as measured by lipid-oxidation levels. 


\section{Materials and Methods}

The experiment was conducted at the Farm School of the Universidade Estadual de Londrina. The test group consisted of 24 barrows from commercial genetic lines, with an average initial weight of $75.408 \pm 4.407 \mathrm{~kg}$. The animals were housed in individual pens, where they received food and water ad libitum during the 28-day experimental period.

The experimental design used was that of randomized blocks with four treatments and six replicates. The initial weights of the animals were taken into consideration for block formation. The pigs were divided into four groups for the characterized treatments (the period during which they ingested the experimental diets). The treatments were as follows: $\mathrm{T} 0$, control feed for 28 days; 7 , test feed for seven days prior to slaughter; T14, test feed for 14 days prior to slaughter; and T21, test feed for 21 days prior to slaughter.

Two feeds were prepared: control feed and test feed, the latter with 50\% DCGF. Both were formulated according to the NRC (1998) to meet the minimum requirements for growing-finishing pigs. The feed compositions and their nutritional values are shown in Table 1. The chemical composition of the DCGF was determined according to the methodology proposed by the AOAC (1984).

Table 1. Component percentages and calculated compositions of experimental feeds.

\begin{tabular}{|c|c|c|}
\hline Ingredients & Feed 0\% DCGF & Feed 50\% DCGF \\
\hline Corn $(\%)$ & 72.187 & 33.546 \\
\hline Soybean bran $(\%)$ & 14.991 & 10.832 \\
\hline Defatted corn-germ flour $(\%)$ & 0 & 50.000 \\
\hline Inert $(\%)$ & 7.102 & 0 \\
\hline Soybean oil (\%) & 2.500 & 2.647 \\
\hline Dicalcium phosphate (\%) & 1.846 & 1.081 \\
\hline Limestone $(\%)$ & 0.674 & 1.167 \\
\hline Vitamin Supplement ${ }^{1}(\%)$ & 0.400 & 0.400 \\
\hline Salt & 0.250 & 0.250 \\
\hline Mineral suplement ${ }^{2}(\%)$ & 0.050 & 0.050 \\
\hline Lysine $(\%)$ & 0 & 0.027 \\
\hline \multicolumn{3}{|l|}{ Calculated Values $^{3}$} \\
\hline Calcium (\%) & 0.800 & 0.800 \\
\hline Digestible energy $(\mathrm{kcal} / \mathrm{kg})$ & 3250 & 3250 \\
\hline Crude fiber (\%) & 4.662 & 3.193 \\
\hline Total phosphorus (\%) & 0.600 & 0.600 \\
\hline Digestible phosphorus (\%) & 0.390 & 0.390 \\
\hline Fat $(\%)$ & 5.127 & 5.112 \\
\hline Lysine (\%) & 0.611 & 0.600 \\
\hline Methionine (\%) & 0.220 & 0.235 \\
\hline Crude protein $(\%)$ & 13.200 & 13.200 \\
\hline Phytic acid $(\%)^{4}$ & 0.840 & 2.140 \\
\hline
\end{tabular}

${ }^{1}$ Vitamin supplement per kg of product: vit. A, 550,000 IU; vit. D3, 150,000 IU; vit. E, 2,500 IU; vit. K3, $550 \mathrm{mg}$; vit. B1, 175 mg; vit. B2, $900 \mathrm{mg}$; vit. B12, 3,000 mcg; folic acid, $150 \mathrm{mg}$; pantothenic acid, 3,000 mg; niacin, 4,750 mg; selenium, $75 \mathrm{mg}$; antioxidant, $2.5 \mathrm{~g}$.

${ }^{2}$ Mineral supplement per kg: Fe, 90,000 mg; Cu, 16,000 mg; Mg, 30,000 mg; Zn, 140,000mg; Co, 200 mg; I, 850 mg; Se, 120 mg.

${ }^{3}$ Calculated based on the EMBRAPA tables (1991)

${ }^{4}$ Quantified in corn, soybean meal and defatted corn-germ flour (Latta; Eskin, 1980 and modified by Ellis; Morris, 1986).

Source: Elaboration of the authors. 
Animals were weighed and feed consumption measured weekly, allowing for the determination of average daily weight gain, daily feed intake and feed conversion.

With an average weight of $104.554 \pm 4.807$ $\mathrm{kg}$, the animals were slaughtered in a regional slaughterhouse following the routine for commercial slaughter. Slaughter consisted of stunning with an electric current using Petrovina ${ }^{\circledR}$ IS2000 equipment, with two electrodes, using 350 volts and $1.3 \mathrm{amps}$. The shock was applied for a period of approximately three seconds. The bleeding was performed by sectioning of the large neck vessels, with the animals upright, suspended by the hind limbs. Carcasses, without the skull and with mask preservation, were individually weighed at the end of slaughter and after 24 hours, to obtain the hot carcass weight, cold carcass weight, carcass yield and carcass weight loss on cooling. The characteristics of carcass length, backfat thickness, muscle depth and loin-eye area were individually measured in refrigerated right half-carcasses 24 hours after slaughter, enabling the calculation of carcass meat yield and carcass meat quantity (BRIDI; SILVA, 2009).

At approximately 24 hours after slaughter, longissimus dorsi samples were collected from the left half-carcasses and sent to the Animal Products Laboratory, Universidade Estadual de Londrina. In the laboratory, the muscles were processed, the extramuscular (subcutaneous) fat was removed and cross-sections (caudal-cranial) of the muscles were performed, resulting in 3-cm-thick steaks, on which the following analyses were performed: color and marbling 24 hours after slaughter, color and lipid oxidation seven days after slaughter (when kept refrigerated at $4^{\circ} \mathrm{C}$ and protected from light), color and lipid oxidation 50 days after slaughter (in samples frozen at $-4^{\circ} \mathrm{C}$ and protected from light) and drip water loss.

The marbling assessment was done by the indirect method, using a panel of comparisons, according to methods of the AMSA (2001), where scores from
1 to 5 were assigned $(1=$ traces of marbling and 5 = abundant marbling). The color was measured using a Minolta ${ }^{\circledR}$ CR-10 portable colorimeter with an integrating sphere and an illumination angle of $8^{\circ}$, i.e., an $8 / d$ viewing geometry, and illuminant D65. The components $L^{*}$ (lightness), a* (redgreen) and $b^{*}$ (yellow-blue) were expressed in the CIELAB system. With these values, it was possible to calculate the saturation index $\left(\mathrm{c}^{*}\right)$ and hue angle $\left(h^{*}\right)$.

The dripping method was used to assess meat water loss (BOCCARD et al., 1981). For the lipidoxidation analysis, the thiobarbituric acid-reactive substances (TBARS) indicator method was used, according to Tarladgis, Pearson and Dugan (1964).

The results were submitted to an analysis of variance with a polynomial derivation (regression).

\section{Results and Discussion}

The total of amounts of phytic consumed acid during the experiment were calculated from the concentration of phytic acid in the feed, the average feed intake and the intake period for each feed composition at 764.60, 1,066.03, 1,374.25 and $1,643.01 \mathrm{~g}$ in the treatments for $0,7,14$ and 21 days, respectively, indicating that DCGF was the major source of endogenous phytic acid.

The DCGF used in this study had the following composition as delivered: $12.65 \%$ moisture, $10.72 \%$ crude protein, $4.69 \%$ ash, $3.67 \%$ crude fiber and $2.49 \%$ ethereal extract. The crude protein content of the DCGF was similar to that found by previous researchers testing DCGF in pig feed (MOREIRA et al., 2002, SOARES et al., 2004; COSTA, 2005), and the values for ethereal extract and phytic acid were similar to those found by Costa (2005). Variations in the composition of this ingredient are expected because changes in soil conditions, climate and cultivars may affect the composition of foods such as corn and corn coproducts (RODRIGUES et al., 2001). Regarding phytic acid, the DCGF used in this 
experiment contained $3.39 \%$ in the fresh material, a value similar to those reported by other authors (LEAL, 2000; COSTA, 2005).

The performance-related data are presented in Table 2. There was no significant regression $(\mathrm{P}>0.05)$ fitting the performance parameters. The presence of DCGF did not affect feed-performance parameters, indicating that it can be used for up to 21 days preceding slaughter at a rate of up to $50 \%$ of the feed. These results are similar to those found by Harbach et al. (2007), who supplemented feed with $40 \%$ DCGF for 28 days prior to slaughter without effects on performance. However, Moreira et al. (2002), when testing the addition of DCGF at up to $45 \%$, reported a quadratic effect in the growingfinishing phase, with a minimum point (at $23.1 \%$ DCGF) for the daily feed intake and decreasing linear effect on daily weight gain and feed conversion. Soares et al. (2004), with the inclusion of up to $40 \%$ DCGF in the growing-finishing phase, found a negative linear effect on daily feed intake. However, these variations may result from differences in DCGF composition such as energy value, which also varies depending on the type of extraction and corn source.

Table 2. Effects of different feeding periods of feed supplemented with $50 \%$ defatted corn-germ flour prior to slaughter in growing-finishing pigs on the average daily gain (ADG), daily feed intake (DFI) and feed conversion (FC).

\begin{tabular}{lccc}
\hline \multirow{2}{*}{ Period (days) } & & Parameters & \\
\cline { 2 - 4 } & ADG $(\mathbf{k g})$ & DFI $(\mathbf{k g})$ & FC \\
\hline day 0 & 1.083 & 3.251 & 3.006 \\
7 days & 1.043 & 3.268 & 3.154 \\
14 days & 1.109 & 3.294 & 2.973 \\
21 days & 1.083 & 3.233 & 3.006 \\
\hline Regression & NS & NS & NS \\
\hline Coefficient of Variation $(\%)$ & 12.44 & 10.37 & 6.84 \\
\hline
\end{tabular}

NS: not significant $(\mathrm{P}>0.05)$.

Source: Elaboration of the authors.

The values for the carcass evaluations are shown in Table 3. The inclusion of 50\% DCGF in the pig feed had no deleterious effects on carcass characteristics $(\mathrm{P}>0.05)$ when included for between 0 and 21 days before slaughter. Moreira et al. (2002) and Soares et al. (2004), evaluating the carcass characteristics of pigs fed with the addition of up to $45 \%$ DCGF, found no effect of the inclusion on these parameters. However, Harbach et al. (2007) found higher carcass yield and muscle depth in treatments with greater inclusion of DCGF (40\%) during the final 28 days of the growing-finishing phase.

The period of DCGF inclusion had no effect on the composition of the meat, water-holding capacity or quantity of intramuscular fat (Table 4). Additionally, for the characteristic color, there were no differences among the values of $\mathrm{L}^{*}, \mathrm{a}^{*}$, $b^{*}, c^{*}$ or $h^{*}$ in the samples stored for different times and temperatures (Table 5), indicating that this ingredient may be used in animal diets without deleterious effects on the sensory and physicochemical characteristics of the meat. 
Table 3. Effects of different feeding periods of feed supplemented with $50 \%$ defatted corn-germ flour in growingfinishing pigs on the hot carcass weight $(\mathrm{HCW})$, cold carcass weight $(\mathrm{CCW})$, carcass yield $(\mathrm{CY})$, carcass refrigeration loss (CRL), carcass length (CL), backfat thickness (BT), muscle depth (MD), loin-eye area (LEA), carcass meat yield (CMY), carcass meat amount (CMA).

\begin{tabular}{|c|c|c|c|c|c|c|c|c|c|c|}
\hline \multirow{2}{*}{$\begin{array}{l}\text { Period } \\
\text { (days) }\end{array}$} & \multicolumn{10}{|c|}{ Parameters } \\
\hline & HCW (kg) & $\begin{array}{c}\text { CCW } \\
\text { (kg) }\end{array}$ & $\begin{array}{l}\text { CY } \\
(\%)\end{array}$ & $\begin{array}{c}\text { CRL } \\
(\%)\end{array}$ & $\begin{array}{c}\text { CL } \\
(\mathrm{cm})\end{array}$ & $\begin{array}{c}\text { BT } \\
(\mathbf{m m})\end{array}$ & $\begin{array}{c}\text { MD } \\
(\mathrm{mm})\end{array}$ & $\begin{array}{l}\text { LEA } \\
\left(\mathrm{cm}^{2}\right)\end{array}$ & $\begin{array}{c}\text { CMY } \\
(\%)\end{array}$ & $\begin{array}{c}\text { CMA } \\
\text { (kg) }\end{array}$ \\
\hline day 0 & 79.90 & 77.74 & 76.31 & 2.69 & 90.80 & 1.54 & 6.09 & 48.07 & 59.72 & 46.43 \\
\hline 7 days & 79.27 & 77.29 & 76.77 & 2.49 & 90.83 & 1.40 & 6.18 & 46.27 & 59.81 & 46.23 \\
\hline 14 days & 79.84 & 77.78 & 75.65 & 2.59 & 93.08 & 1.27 & 5.95 & 45.84 & 59.87 & 46.56 \\
\hline 21 days & 80.46 & 78.47 & 76.90 & 2.47 & 89.75 & 1.41 & 6.08 & 45.07 & 59.79 & 46.91 \\
\hline Regression & NS & NS & NS & NS & NS & NS & $\mathrm{NS}$ & NS & NS & NS \\
\hline$\overline{C V}(\%)$ & 3.47 & 3.46 & 1.22 & 8.93 & 2.57 & 14.88 & 12.81 & 11.26 & 0.27 & 3.41 \\
\hline
\end{tabular}

NS: Not significant $(\mathrm{P}>0.05)$; $\mathrm{CV}$ : Coefficient of variation.

Source: Elaboration of the authors.

Table 4. Effects of different feeding periods of feed supplemented with $50 \%$ defatted corn-germ flour in growingfinishing pigs on drip loss and marbling in pork loin.

\begin{tabular}{|c|c|c|}
\hline \multirow{2}{*}{$\begin{array}{l}\text { Period } \\
\text { (days) }\end{array}$} & \multicolumn{2}{|c|}{ Parameters } \\
\hline & Drip loss (\%) & Marbling *1 \\
\hline day 0 & 7.400 & 1.00 \\
\hline 7 days & 6.555 & 2.00 \\
\hline 14 days & 6.307 & 1.50 \\
\hline 21 days & 6.418 & 2.17 \\
\hline Regression & NS & NS \\
\hline Coefficient of Variation (\%) & 24.03 & 44.72 \\
\hline
\end{tabular}

${ }^{* 1} 1<$ marbling $<7$, with 1 meaning only trace marbling and 7 meaning excessive marbling

NS - not significant ( $\mathrm{P}>0.05)$.

Source: Elaboration of the authors. 
Table 5. Effects of different feeding periods of feed supplemented with $50 \%$ defatted corn-germ flour in growingfinishing pigs on lightness $\left(\mathrm{L}^{*}\right)$, red-green component $\left(\mathrm{a}^{*}\right)$, yellow-blue component $\left(\mathrm{b}^{*}\right)$, saturation index $\left(\mathrm{c}^{*}\right)$ and hue angle $\left(\mathrm{h}^{*}\right)$ in loin on the day of sample collection (day 0 ), in the loin kept under refrigeration for seven days (day $7)$ and in loin frozen for 50 days (50 days).

\begin{tabular}{|c|c|c|c|c|c|}
\hline \multirow{2}{*}{$\begin{array}{l}\text { Period } \\
\text { (days) }\end{array}$} & \multicolumn{5}{|c|}{ Day 0} \\
\hline & $\mathbf{L}^{* 1}$ & $\mathbf{a}^{* 2}$ & $\mathbf{b}^{* 3}$ & $\mathbf{c}^{* 4}$ & $\mathbf{h} * 5$ \\
\hline day 0 & 53.860 & 0.495 & 9.907 & 9.937 & 87.335 \\
\hline 7 days & 52.045 & 0.957 & 9.248 & 9.312 & 84.273 \\
\hline 14 days & 53.397 & 0.445 & 9.252 & 9.303 & 87.852 \\
\hline 21 days & 52.648 & 0.705 & 9.445 & 9.477 & 85.830 \\
\hline Regression & NS & NS & NS & NS & NS \\
\hline Coefficient of Variation (\%) & 4.75 & 110.60 & 14.34 & 14.53 & 4.818 \\
\hline \multirow{2}{*}{$\begin{array}{c}\begin{array}{c}\text { Period } \\
\text { (days) }\end{array} \\
\end{array}$} & \multicolumn{5}{|c|}{ Day 7} \\
\hline & $\mathbf{L} * 1$ & $a^{* 2}$ & $\mathbf{b}^{* 3}$ & $c^{* 4}$ & $\mathbf{h} * 5$ \\
\hline day 0 & 55.855 & 1.303 & 10.520 & 10.613 & 83.032 \\
\hline 7 days & 53.380 & 1.260 & 9.613 & 9.712 & 82.855 \\
\hline 14 days & 53.260 & 0.963 & 9.600 & 9.667 & 84.397 \\
\hline 21 days & 54.620 & 1.308 & 9.900 & 10.000 & 82.603 \\
\hline Regression & NS & NS & NS & NS & NS \\
\hline Coefficient of Variation (\%) & 4.19 & 60.17 & 8.39 & 8.98 & 4.40 \\
\hline \multirow{2}{*}{$\begin{array}{c}\begin{array}{c}\text { Period } \\
\text { (days) }\end{array} \\
\end{array}$} & \multicolumn{5}{|c|}{ Day 50} \\
\hline & $L^{* 1}$ & $a^{* 2}$ & $\mathbf{B} * 3$ & $c^{* 4}$ & $h * 5$ \\
\hline day 0 & 55.308 & 5.153 & 10.348 & 11.577 & 63.603 \\
\hline 7 days & 55.145 & 4.623 & 9.978 & 11.028 & 65.335 \\
\hline 14 days & 54.943 & 4.450 & 10.122 & 11.102 & 66.820 \\
\hline 21 days & 56.630 & 4.860 & 10.423 & 11.515 & 65.183 \\
\hline Regression & NS & $\mathrm{NS}$ & NS & NS & NS \\
\hline Coefficient of Variation (\%) & 4.19 & 26.14 & 11.59 & 13.16 & 6.60 \\
\hline
\end{tabular}

$\mathrm{NS}$ - not significant $(\mathrm{P}>0.05)$

${ }^{1} 0 \leq \mathrm{L}^{*} \leq 100$ corresponds to a range of lightness from black to white

${ }^{2}-\mathrm{a}^{*}$ to $+\mathrm{a}^{*}$ corresponds to a range of hues from green to red

${ }^{3}-b^{*}$ to $+b^{*}$ corresponds to a range of hues from blue to yellow

${ }^{4} \mathrm{c}^{*}=\left(\mathrm{a}^{* 2}+\mathrm{b}^{* 2}\right)^{0,5}$

${ }^{5} \mathrm{~h} *=\tan -1(\mathrm{~b} * / \mathrm{a} *)$.

Source: Elaboration of the authors. 
Figure 1 show the results of the lipid-oxidation analysis of pork-loin samples kept refrigerated for seven days. A decreasing linear effect $(\mathrm{P} \leq 0.05)$ was observed in refrigerated pork $(\mathrm{y}=0.04646-$ $0.00102238 \mathrm{x})$. There was a $46.24 \%$ reduction in lipid oxidation with the inclusion of 50\% DCGF for the 21 days prior to animal slaughter compared to the unsupplemented diet ( 0 days treatment). The effect of DCGF inclusion was not observed $(\mathrm{P}>0.05)$ in the frozen loin, probably because the samples were stored frozen and protected from light. The TBARS values for the samples stored frozen was 0.1457 , $0.1746,0.1203$ and $0.1084 \mathrm{mg} / \mathrm{kg}$ in the treatments for $0,7,14$ and 21 days, respectively.

Figure 1. TBARS values $(\mathrm{mg} / \mathrm{kg})$ of pork loin kept refrigerated for seven days from pigs that received $50 \%$ defatted corn-germ flour for different periods prior to slaughter; $y=0.04646-0.00102238 \mathrm{x}(\mathrm{P} \leq 0.05)$.

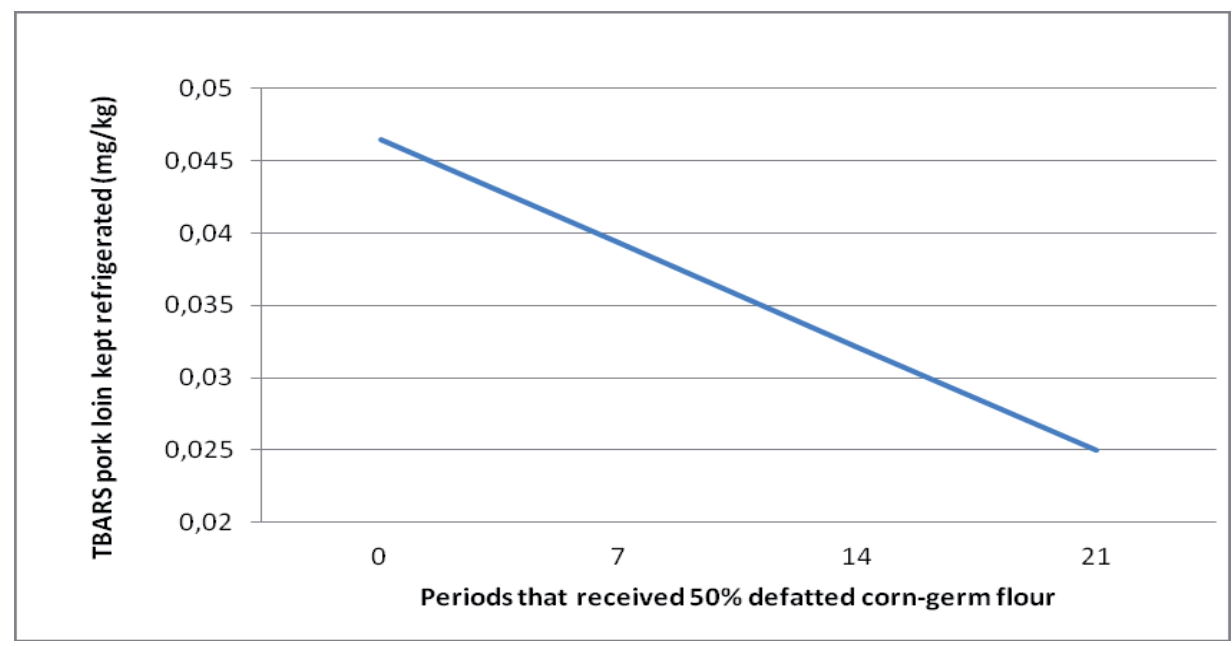

Source: Elaboration of the authors.

These results support the hypothesis that dietary phytic acid supplementation can result in increased antioxidant activity in pork. According to Grases, Simonet and Prieto (2001), all the inositol hexaphosphate present in the body comes from the feed, and the muscle tissue is the main storage site. This hypothesis was also supported by Harbach et al. (2007) and Costa (2005), who tested the inclusion of up to $40 \%$ of DCGF in pig feed for 28 days and found a lower oxidation level in refrigerated and frozen pork in the treatments with higher rates of DCGF addition.

\section{Conclusions}

The inclusion of $50 \%$ of DCGF in swine feed provided for different periods during the growing- finishing phase did not influence the zootechnical results, the carcass characteristics or the meat quality. The inclusion of this ingredient was found to increase the shelf life of refrigerated pork, with preservation being proportional to the inclusion period prior to animal slaughter.

\section{Acknowledgments}

Authors would like to thank Fundação Araucária de Apoio ao Desenvolvimento Científico e Tecnológico do Paraná for the financial support to the Project.

The experiment was approved by the Ethics Committee on Animal Experimentation of the Universidade Estadual de Londrina, Londrina, Brazil (N. 116/2008). 


\section{References}

AMERICAN MEAT SCIENCE ASSOCIATION AMSA. Meat evaluation handbook. Savoy: American Meat Science Association, 2001. p. 15-74.

ASSOCIATION OF OFFICIAL ANALYTICAL CHEMISTS - AOAC. Official methods of analysis. $14^{\text {th }}$ ed. Washington: Association of Official Analytical Chemists, 1984.

BOCCARD, R.; BUCHTER, L.; CASTEELS, E.; COSENTINO, E.; DRANSFIELD, E.; HOOD, D. E.; JOSEPH, R. L.; MACDOUGALL, D. B.; RHODES, D. N.; SCHÖN, I.; TINBERGEN, B. J.; TOURAILLE, C. Procedures for measuring meat quality characteristics in beef production experiments. Livestock Production Science, Amsterdam, v. 8, n. 5, p. 385-397, 1981.

BRIDI, A. M.; SILVA, C. A. Avaliação da carne suína. Londrina: Midiograf, 2009. 120 p.

COSTA, M. C. R. Farelo de gérmen de milho desengordurado na alimentação de suínos como fonte de ácido fitico. 2005. Dissertação (Mestrado em Ciência Animal) - Universidade Estadual de Londrina, Londrina.

DUTHIE, G. G. Lipid peroxidation. European Journal of Clinical Nutrition, London, v. 47, n. 11, p. 759-764. 1993.

EMPSON, K. L.; LABUZA, T. P.; GRAF, E. Phytic acid as a food antioxidant. Journal of Food Science, Chicago, v. 56, n. 2 , p. $560-563,1991$.

FERRARI, C. K. B. Oxidação de lipídios e antioxidantes: importância nas ciências animal e dos alimentos. Higiene Alimentar, São Paulo, v. 60, n. 13, p. 16-19, 1999.

FIREMAN, F. A. T.; FIREMAN, A. K. B. A. T. Enzimas na alimentação de suínos. Ciência Rural, Santa Maria, v. 28, n. 1, p. 173-178, 1998.

GHIRETTI, G. P.; ZANARDI, E.; NOVELLI, E.; CAMPANINI, G.; DAZZI, G.; MADARENA G.; CHIZZOLINI, R. Comparative evaluation of some antioxidants in salame milano and mortadella production. Meat Science, Barking, v. 47, n. 1, p. 167-176, 1997.

GRAF, E.; EATON, J. W. Antioxidant functions of phytic acid. Free Radical Biology \& Medicine, New York, v. 8, n. 1, p. 61-69, 1990.

GRASES, F.; SIMONET, B. M.; PRIETO, R. M.; MARCH, J. G. Variation of InsP4, InsP5 and InsP6 levels in tissues and biological fluids depending on dietary phytate. The Journal of Nutritional Biochemistry, v. 12, n. 10, p. 595-561, 2001.
HARBACH, A. P. R.; COSTA, M. C. R.; SOARES, A. L.; BRIDI, A. M.; SHIMOKOMAKI, M.; SILVA, C. A.; IDA, E. I. Dietary corn germ containing phytic acid prevents pork meat lipid oxidation while maintaining normal animal growth performance. Food Chemistry, London, v. 100, n. 4, p. 1630-1633, 2007.

JARIWALLA， R. J.; SABIN, R.; LAWSON, S.; HERMAN, Z. S. Lowering of serum cholesterol and triglycerides and modulation of divalent cations by dietary phytate. Journal of Applied Nutrition, v. 42, n. 1, p. 18-28, 1990.

LEAL, E. S. Extração, obtenção e caracterização parcial de ácido fitico do germe grosso de milho e aplicação como antioxidante. 2000. Dissertação (Mestrado em Ciência de Alimentos) - Universidade Estadual de Londrina, Londrina.

LEE, B. J.; HENDRICKS, D. G. Phytic acid protective effect against beef round muscle lipid peroxidation. Journal of Food Science, Chicago, v. 60, n. 2, p. 241244, 1995.

MOREIRA, I.; RIBEIRO, C. R.; FURLAN, A. C.; SCAPINELLO, C.; KUTSCHENKO, M. Utilização do farelo de germe de milho desengordurado na alimentação de suínos em crescimento e terminação - digestibilidade e desempenho. Revista Brasileira de Zootecnia, Viçosa, v. 31, n. 6, p. 2238-2246, 2002.

MORRISSEY, P. A.; SHEEHY, P. J. A.; GALVIN, K.; KERRY, J. P.; BUCKLEY, D. J. Lipid stability in meat and meat products. Meat Science, Barking, v. 49, p. s73-s86. 1998. Supplement 1.

NATIONAL RESEARCH COUNCIL - NRC. Nutrient requeriments of swine. $10^{\text {th }}$ ed. Washington: National Academy Press, 1998.

RODRIGUES, P. B.; ROSTAGNO, H. S.; ALBINO, L. F. T.; GOMES, P. C.; BARBOZA, W. A.; SANTANA, R. T. Valores energéticos do milheto, do milho e subprodutos do milho, determinados com frangos de corte e galos adultos. Revista Brasileira de Zootecnia, Viçosa, v. 30, n. 6, p. 1767-1778, 2001.

SAKAMOTO, K.; VUCENIK, I.; SHAMSUDDIN, A. M. $\left[{ }^{3} \mathrm{H}\right]$ Phytic acid (inositol hexaphosphate) is absorbed and distributed to various tisues in rats. Journal of Nutrient Metabolism, New York, v. 4, n. 123, p. 713-720, 1993.

SELLE, P. H.; RAVINDRAN, V.; CALDWELL, R. A.; BRYDEN, W. L. Phytate and phytase: consequences for protein utilisation. Nutrition Research Rewiews, Cambridge, v. 13, p. 255-278, 2000. 
SEYNAEVE, M.; JANSSES, G.; HESTA, C.; NEVEL, V.; WILDE, R. O. Effects of dietary $\mathrm{Ca} / \mathrm{P}$ ratio, $\mathrm{P}$ level and microbial phytase supplementation on nutrient digestibilities in growing pigs: breakdown of phytic acid, partition of $\mathrm{P}$ and phytase activity along the intestinal tract. Journal Animal Physiology and Animal Nutrition, Malden, v. 83, n. 4-5, p. 193-204, 2000.

SOARES, L. L. P.; SILVA, C. A.; PINHEIRO, J. W.; FONSECA, N. A. N.; CABRERA, L.; HOSHI, E. E.; SILVA, M. A. A.; CANTERI, R. C. Farelo de gérmen de milho desengordurado na alimentação de suínos em crescimento e terminação. Revista Brasileira de Zootecnia, Viçosa, v. 33, n. 1, p. 1768-1776, 2004.
TARLADGIS, B. G.; PEARSON, A. M.; DUGAN JÚNIOR, L. R. Chemistry of the 2-thiobarbituric test for determination of oxaditive rancidity in foods II. Formation of the TBA-malonaldehyde complex without acid-heat treatment. Journal of Food Science and Agriculture, Malden, v. 15, n. 9, p. 602-604, 1964.

ZHOU, J. R.; ERDMAN JUNIOR, J. W. Phytic acid in health and disease. Critical Reviews in Food Science and Nutrition, Boca Raton, v. 35, n. 6, p. 495-508, 1995. 